\title{
Knowledge and attitudes of intern physicians on nutritional ergogenic supplementation and doping*
}

\section{Intörn hekimlerin besinsel ergojenik destek ürünleri ile doping konusundaki bilgileri ve tutumları*}

\author{
Sabriye Ercan (iD, Ahsen Oğul iD, Ayhan Canbulut iD, Esma Arslan (iD, Cem Çetin iD \\ Sports Medicine Department, Faculty of Medicine, Süleyman Demirel University, Isparta, Turkey
}

\begin{abstract}
Objective: The history of doping in sports goes back thousands of years. It is known that athletes used performance-enhancing agents in ancient games. Nutritional ergogenic supplements are also items that athletes have used for years to increase performance or supplement their missing nutrients. If an ergogenic supplement increases performance above physiological limits, it is prohibited. Increased knowledge of physicians regarding the fight against doping and the use of supplements is important for protecting health of athletes. It is the physician's responsibility to take care of athletes' health, to evaluate performance capacity, to give nutritional advice and to monitor substances being used. In this study, it was aimed to determine the levels of knowledge of intern physicians about nutritional ergogenic supplementation and doping, and to determine their attitudes and the factors affecting their attitudes.
\end{abstract}

Materials and Methods: Intern physicians who were students in the 2019-2020 academic year were voluntarily enrolled in the study. Participants' 'levels of knowledge about nutritional ergogenic supplementation and doping' were measured. Their attitudes were evaluated with the Nutrition Ergogenic Supplement Attitude Measurement and the Scale of Attitude Towards Use of Doping.

Results: A total of 153 (58 male, 95 female) intern physicians participated in the study voluntarily. It was determined that 31 (20.3\%) of the participants had used ergogenic supplements and $2(1.3 \%)$ had used the products within the scope of doping. To the questions about nutritional ergogenic supplements and doping, 60\% replied "I have no idea" and 29.9\% replied "I have heard."

Conclusion: In this study, the level of knowledge of the intern physicians about nutritional ergogenic supplements and doping was found insufficient. No relation was found between attitudes and the answers given to the questions measuring the level of knowledge. It is necessary to increase the knowledge of physicians in this field.

Keywords: Doping, nutritional ergogenic supplement, knowledge, attitude, physician

\section{öz}

Amaç: Sporda doping kullanımının geçmişi binlerce yıl önceye dayanmaktadır. Antik oyunlarda sporcuların performans arttııcı maddeler kullandıkları bilinmektedir. Besinsel ergojenik destek ürünleri de sporcuların yıllardır performansı arttırmak ya da eksik besinlerini tamamlamak üzere kullandıklan maddelerdir. Eğer bir ergojenik destek ürününün kullanımı performansı fizyolojik sıııların üzerine çıkarıısa, bu maddenin kullanımı yasaklanır. Hekimlerin dopingle mücadele ve besinsel ergojenik destek ürünü kullanımı ile ilgili artmış bilgisi, sporcu sağlı̆ını korumak için son derece önem teșkil etmektedir. Sporcuların sağlığına ve refahına özen göstermek, performans kapasitesini değerlendirmek, beslenme önerileri vermek, reçete yazmak ve madde kullanımı izlemek hekimin sorumluluğu altındadır. Bu çalışmada, intörn hekimlerin besinsel ergojenik destek ürünleri ile doping konusundaki bilgi düzeylerinin ve tutumlarının belirlenmesi, tutumlarına etki eden ve tutumları ile ilişkili olan faktörlerin saptanması amaçlanmıştır.

Gereç ve Yöntem: Tanımlayıcı nitelikteki bu çalıșmaya, 2019-2020 eğitim-öğretim ylında intörn olan hekimler gönüllü olarak dahil edilmiștir. Katılımcıların 'besinsel ergojenik destek ürünleri ve doping konusundaki bilgi düzeyi' sorgulanmıştır. Katılımcıların tutumları ise 'Besinsel ergojenik destek ürünlerine yönelik tutum (BEDT) ölçeği' ve 'Doping kullanımına yönelik tutum (DKT) ölçeği' ile değerlendirilmiştir.

Bulgular: Çalıșmaya 153 (58 erkek, 95 kadın) intörn hekim gönüllü olarak katılısștır. Katııımcıların 31'inin (\%20,3) ergojenik destek ürünü, 2'sinin (\%1,3), doping kapsamına giren ürün kullanımının mevcut olduğu saptanmıştır. 'Besinsel ergojenik destek ürünleri ve doping konusundaki bilgi düzeyi' sorularına \%60 \pm 1.9 'Hiçbir fikrim yok' ve \%29.9 \pm 1,6 'Duymuştum' cevabı verilmiştir.

Sonuç: Bu çalıșmanın sonucunda, intörn hekimlerin besinsel ergojenik destek ürünleri ile doping konusundaki bilgi düzeyleri yetersiz bulunmuștur. Bilgi düzeyini ölçen sorulara verilen cevaplar ile tutum arasında bir ilişki saptanamamıştır. Hekimlerin bu alandaki bilgilerinin artırılması gerektiği görülmüştür.

Anahtar Sözcükler: Doping, besinsel ergojenik destek, bilgi, tutum, hekim

\section{INTRODUCTION}

The history of doping in sports goes back thousands of years. It is known that athletes used performance-enhancing

agents in ancient games (1). For the first time in the Olympic Games, illegal substances were detected in biological

Received / Geliş: 26.08.2020 • Accepted / Kabul: 05.03.2021 • Published / Yayın Tarihi: 10.03.2021

Correspondence / Yazışma: Esma Arslan · Süleyman Demirel Üniversitesi Tıp Fakültesi, Spor Hekimliği Ana Bilim Dalı, Isparta, Turkey · esmaarslan.sdu@gmail.com

Cite this article as: Ercan S, Ogul A, Canbulut A, Arslan E, Cetin C. Knowledge and attitudes of intern physicians on nutritional ergogenic supplementation and doping. Turk J Sports Med. 2021;56(2).61-6.; http://dx.doi.org/10.47447/tjsm.0487

${ }^{\star}$ This study was presented as an oral presentation at the Health Services Symposium on the $100^{\text {th }}$ Anniversary of National Struggle, 21 November 2019, held in Isparta, Turkey. 
samples from athletes in 1968, and drug use in athletes has been widely recognized and documented in recent years (2). Although the trend towards doping is not new, it particularly started to increase in the last 40 years and its performance-oriented use has become widespread (3). The International Olympic Committee held the $1^{\text {st }}$ World Congress on Doping in Sports in 1999 and established the World AntiDoping Agency (WADA), (4). The goals and rules of the WADA are intended to protect athletes' rights to participate in sports without doping; to protect health, justice, and equality for all athletes; to identify the use of doping with coordinated international programs, deterring athletes from doing it; and to prevent the practice of doping (5).

Nutritional ergogenic supplements are also items that athletes have used for years to increase performance or supplement their missing nutrients. The most common purpose of using ergogenic supplementation is to increase one's athletic performance. The basic condition for a substance to be included in the WADA's banned list is that the substance improves physical performance beyond physiological limits. Accordingly, if an ergogenic supplement increases performance above physiological limits, it is prohibited (6).

According to the International Olympic Committee, it is the physician's responsibility to take care of the health and well-being of athletes, to treat and prevent injuries, to perform medical examinations, to evaluate performance capacity, to give nutritional advice, to prescribe and supervise training programs, and to monitor substances being used (7). Although many circles are involved in the fight against doping, there are particularly some physicians with a strong sense of responsibility who invite people to fight against doping and play an active role in controlling it (8). In the prescribing process, giving a drug with doping properties to an athlete due to the physician's lack of information is in conflict with sports ethics and may also create potential side effects (9).

The extent and nature of the participation of general practitioners in the practice of doping in sports remains uncertain (9). According to the rules of the WADA, physicians or assistant health personnel prescribing or trying to administer any prohibited substances can be accused of supporting or hiding unethical assistance to aid an athlete inside or outside of competition (10). The first way of preventing such unethical practices involves increasing the physician's knowledge in this field and then fostering attitudes and behaviors that will set positive examples for athletes (9).

In the case of the lack of information about performanceenhancing drugs, athletes' attitudes are mostly towards the practice of doping (11). In a study conducted in France, it was reported that general practitioners lacked the knowled- ge and attitudes required to prevent doping, but they considered doping a public health problem and were ready to play an active role in its elimination (12).

The aim of this study was to examine the knowledge and attitude levels of intern physicians regarding nutritional ergogenic supplements along with doping, and the factors affecting their knowledges and attitudes. Our hypothesis is that increased knowledge about nutritional ergogenic supplementation and doping will have an impact on positive attitudes. We also aimed to reveal the factors that might affect the knowledge and attitudes of the participants, such as; gender, participation in sports and physical activities.

\section{MATERIAL and METHODS}

Physicians who were completing their internship at Medical Faculty in the academic year of 2019-2020 voluntarily enrolled in this descriptive study. The participants did not have lectures about ergogenic supplementation and doping during their medical education. Interns were included in the study because they had completed their theoretical education and would work in the field after graduation. In power analysis (confidence level: 95\%, precision rate: 0.05), the total number of interns was evaluated and it was determined that the sample size should include 147 participants. The study was approved by the local ethics committee.

Participants' demographic data were recorded. Their levels of knowledge about nutritional ergogenic supplements and doping were then evaluated with 20 questions based on the researchers' literature review (13). Participants answered these questions with "I have no idea," "I have heard," or "I know very well." The reliability of the questionnaire prepared by the researchers was analyzed in a sample group. The Cronbach alpha value was found to be at the level of 0.855 , and the measurement tool was found to have high reliability (14).

The intern physicians' attitudes were evaluated with the Nutrition Ergogenic Supplement Attitude Measurement (NESAM), (15) and the Scale of Attitude Towards Use of Doping (SATUD), (16).

In the NESAM scale, benefits, side effects and ethics, and natural nutrition are the 3 sub-dimensions with 13 questions in total. While increases in the score obtained from the benefits sub-dimension express negative attitudes, high scores obtained from the other sub-dimensions express positive attitudes (15). When the reliability of the scale in the sample group was examined, it was found that all sub-dimensions (Cronbach alfa; benefits sub-dimension: 0.843 , side effects and ethics sub-dimension: 0.744 , natural nutrition sub-dimension: 0.647) were reliable (14). 
The SATUD consists of 10 questions. A minimum of 10 and a maximum of 50 points can be obtained from the scale. An increase in the score expresses a positive attitude (16). When the reliability of the scale in the sample group was analyzed, the Cronbach alpha value was found to be 0.897 and the measurement tool was found to have a high reliability (14).

The scales and questionnaires were administered to the participants in a face-to-face environment.

\section{Statistical analysis}

The compliance of the data to normal distribution was tested with the Shapiro-Wilk test. Data were analyzed by descriptive statistical methods with SPSS 23.0 using t-tests, Pearson correlation analysis, and linear regression analysis in independent groups. Values of $p<0.05$ were considered significant. Results are presented as frequency (n) with percentage $(\%)$ or mean \pm standard deviation.

\section{RESULTS}

At the end of the study, the data of 153 intern physicians ( 58 male, 95 female) were analyzed. The mean age of the participants was $24 \pm 1$ years.

Of the intern physicians participating in the study, $17.6 \%$ (n $=27$ ) engaged in regular physical activity. Nineteen $(12.4 \%)$ of them had a known disease and $15(9.8 \%)$ used regular medications to treat their diseases. Thirty-one $(20.3 \%)$ of them used ergogenic supplements. Of those participants, $54.8 \%(\mathrm{n}=17)$ had received information about the supplements from a physician and $84 \%(n=26)$ of them had been using supplementation for less than six months. To obtain the ergogenic supplements, $70.1 \%(\mathrm{n}=22)$ preferred a pharmacy and $25.8 \%(\mathrm{n}=8)$ preferred Internet sales.

It was determined that the intern physicians $(n=2,1.3 \%)$ who used supplements included in the scope of doping were female and aimed to increase their mental performance.

The questions about the knowledge levels of "nutritional ergogenic supplements and doping" were answered as follows: $60 \pm 1.9 \%$ "I have no idea," $29.9 \pm 1.6 \%$ "I have heard," and $10.1 \pm 1.1 \%$ "I know very well."

The mean score of the benefits sub-dimension of the NESAM scale was $2.9 \pm 0.9$ points, that of the adverse effects and ethics sub-dimension was $3 \pm 0.6$ points, and that of the natural nutrition sub-dimension was $3 \pm 0.7$ points. The mean score obtained from the SATUD was $39.9 \pm 7.6$.
When the participants were divided into two groups according to gender, it was seen that the females gave significantly more responses of "I have no idea" $(\mathrm{p}=0.01)$ and "I have heard" ( $p=0.03)$. In addition, the NESAM natural nutrition sub-dimension scores of female participants were found to be lower ( $\mathrm{p}=0.02$ ), (Table 1 ).

In the logistic regression model created by the backward elimination method by taking the SATUD score as an independent variable, the benefits sub-dimension of the NESAM scale remained a variable only among female participants $(\mathrm{p}=0.02)$.

Table 1. Knowledge of, and attitudes towards doping with nutritional ergogenic supplements by gender

$\begin{array}{lccc} & \text { Male ( } \mathbf{n = 5 8 )} & \text { Female (n=95) } & p \\ \text { Knowledge questions (\%) } & & & \\ \text { "I have no idea" } & 53.8 \pm 24.5 & 63.8 \pm 22.2 & 0.01^{*} \\ \text { "I have heard" } & 34.3 \pm 22.5 & 27.2 \pm 17.5 & 0.03^{*} \\ \text { "I know very well" } & 11.9 \pm 14.5 & 9.0 \pm 12.7 & 0.10 \\ \text { NESAM (points) } & & & \\ \text { Benefits } & 3.0 \pm 1.0 & 2.8 \pm 0.8 & 0.40 \\ \text { Adverse effects and ethics } & 3.0 \pm 0.6 & 3.0 \pm 0.6 & 0.80 \\ \text { Natural nutrition } & 3.2 \pm 0.7 & 2.9 \pm 0.7 & 0.02^{*} \\ \text { SATUD (points) } & 39.6 \pm 8.8 & 40.1 \pm 6.8 & 0.70 \\ \text { *: significant at the level of 0.05:NESAM: nutrition ergogenic supplement attitu- } \\ \text { de measurement; SATUD: scale of attitude towards use of doping }\end{array}$

When the data of all participants were examined, it was found that attitudes towards doping were negatively related to the benefits sub-dimension of the NESAM. Some sub-dimensions of the NESAM were found to be associated with the presence of chronic disease, drug use for therapeutic purposes, and participation in physical activity (Table 2). The relationships of other variables with attitude were not established.

When the correlation analysis was deepened in terms of gender, the SATUD and the benefits sub-dimension of the NESAM scale showed negative relationships only in female participants $(\mathrm{p}=0.006, \mathrm{r}=-0.3)$. In addition, in females, the SATUD score and the natural nutrition sub-dimension score of the NESAM showed a positive correlation $(p=0.03$, $r=0.2$ ).

A negative correlation was seen between the adverse effects and ethics sub-dimension of the NESAM and the presence of disease and regular drug use only in females $(p=0.004, r$ $=-0.3 ; p=0.0001, r=-0.3$ ), while a negative correlation was seen with participation of the person in regular physical activity only in males $(p=0.004, r=-0.4)$.

The natural nutrition sub-dimension of the NESAM scale showed a negative relationship with female gender $(p=$ $0.02, r=-0.2)$ and with regular drug use in females $(\mathrm{p}=$ $0.04, \mathrm{r}=-0.2)$. 


\begin{tabular}{|c|c|c|c|c|c|c|}
\hline Disease & $\begin{array}{c}\text { Drug } \\
p=0.0001 \\
r=0.50^{* *}\end{array}$ & $\begin{array}{c}\text { RPA } \\
p=0.40\end{array}$ & $\begin{array}{c}\text { NESAM-B } \\
p=0.40\end{array}$ & $\begin{array}{c}\text { NESAM-AE } \\
p=0.04 \\
r=-0.20^{*}\end{array}$ & $\begin{array}{c}\text { NESAM-NN } \\
p=0.40\end{array}$ & $\begin{array}{l}\text { SATUD } \\
p=0.70\end{array}$ \\
\hline Drug & - & $p=0.30$ & $p=0.50$ & $\begin{array}{l}p=0.002 \\
r=-0.20^{* *}\end{array}$ & $\begin{array}{l}p=0.02 \\
r=-0.20^{*}\end{array}$ & $p=0.90$ \\
\hline RPA & - & - & $p=1.00$ & $\begin{array}{l}p=0.002 \\
r=-0.20^{* *}\end{array}$ & $p=0.90$ & $p=0.60$ \\
\hline NESAM-B & - & - & - & $p=0.40$ & $p=0.70$ & $\begin{array}{c}p=0.03 \\
r=-0.20^{*}\end{array}$ \\
\hline NESAM-AE & - & - & - & - & $\begin{aligned} P & =0.0001 \\
r & =0.40^{* *}\end{aligned}$ & $p=0.80$ \\
\hline NESAM- NN & - & - & - & - & - & $p=0.40$ \\
\hline
\end{tabular}

NESAM- NN

significant at 0.05 level, ${ }^{* *}$ : significant at 0.01 level; $r=0.01-0.29$ :low-level relationship, $r=0.30-0.69$ :medium-level relationship; RPA: regular physical activity; NESAM: nutrition ergogenic supplement attitude measurement; SATUD: scale of attitude towards use of doping; B: benefits; AE: adverse effects and ethics; NN: natural nutrition.

\section{DISCUSSION}

In our study, it was determined that the levels of knowledge of the intern physicians on nutritional ergogenic supplements and doping were not sufficient. It was also determined that intern physicians use substances that have the effect of increasing mental performance within the scope of doping. The answers given to the questions that measured levels of knowledge were not related to attitudes.

It has been determined that the attitude towards the use of nutritional ergogenic supplements in females is related to and effective on attitudes towards doping. The attitude towards the use of nutritional ergogenic supplements in females is based on the presence of chronic diseases and drug use for treatment, while it was found to be associated with male participants' engagement in physical activity.

In our study, most of the users of ergogenic supplements received information from their physicians. Pharmacies were the most popular option for obtaining ergogenic supplements, and the second was Internet sales. Argan and Köse reported that gyms were the most popular place to obtain ergogenic supplements, followed by the Internet, pharmacies, and markets, and advice from friends was the primary method of obtaining information (15). In another study, athletes (42.5\%), the media $(25.8 \%)$, and circles of friends $(25 \%)$ had important effects in providing information about these products (15). It was thought that the medical education of the group we evaluated in our study affected their sources of information and choices of product supply.

Three factors were identified in a previous study that influence attitudes towards products used as supplements in sports. These were benefits, natural nutrition, and adverse effects and ethics. Minerals, carbohydrates, and other nutritional elements are lost during exercises. The factor of benefits, which emphasizes that ergogenic support products should be used to support personal health, reflects a positive situation. The adverse effects and ethics factor, including the problems of the legal use of these products, adverse health effects, and doping effects, reflect the most negative attitudes among all factors. The natural nutrition factor, which reveals that athletic performance can be achieved without taking any supplemental products, seems to be the opposite of the benefits factor (15). Ercen found that the average scores of athletes from the "benefits" sub-dimensions of the attitude scale towards nutri- tional ergogenic support products were related with the use of ergogenic supplements. They showed that this relationship is directly proportional to the "benefits" sub-dimension and inversely proportional to the "side effects and ethics" and "natural nutrition" sub-dimensions. Ercen concluded that people's attitudes are an important factor affecting the use of supplements. When the results of the attitude scale were further analyzed, the participants who believed that natural nutrition was sufficient and that there were adverse effects of the products were less prone to use the products. Although the idea that ergogenic supplements are necessary for sports was dominant in that study, the majority of the group was of the opinion that these products are not used correctly (17). In our study, the adverse effects and ethics sub-dimension of the NESAM scale were found to be negatively related to presence of disease, regular drug use, and participation in regular physical activity. The natural nutrition sub-dimension was negatively related to regular drug use only in females. This is thought to be due to professional positions, such as being an athlete or a physician.

Şapçı reported that the arithmetic average of SATUD scores was 19.84 (16), which is half of the average score that we found in our study. Şapçı further reported that the studied athletes generally had attitudes opposed to doping. However, doping participants did have positive attitudes towards doping, especially with the answers they gave to the statement "I can use doping for the success of my country in an international sports organization." The athletes stated that they would use doping to ensure their success despite the risks. It was concluded that the athletes thought that doping was inappropriate from an ethical point of view, but they believed that such substances are necessary to increase sportive performance (16). Sinan et al. studied 100 male bodybuilding athletes and found that $11 \%$ of the participants answered "yes" to "Would you use medication that guarantees that you will be the champion even if you know that you will die as a result?" (18). It seems that the attitudes of intern physicians towards the fight against doping are more positive than those in athletes.

It is thought that the knowledge of young physicians about doping in sports and especially sports medicine is limited due to the insufficient medical studies on this subject (3). Laure et al., in a study conducted in France, stated that general practitioners have limited knowledge of the daily practices of doping and are faced 
with demands for prescribing doping agents (19). Greenway and Greenway stated that only one-third of their participants knew that information about prohibited substances in sports was available in official guidelines, that the general knowledge of general practitioners about banned substances in sports was low, and that this reflected the lack of education in medical schools (20). In our study, in accordance with the literature, it was determined that the knowledge of the intern physicians in this area was insufficient.

Anabolic steroids continue to be popular among bodybuilders and strength athletes despite warnings about their side effects (20). Perry et al. showed that the prevalence of anabolic steroid use in some gyms is $35 \%$ (21). In a study of general practitioners in West Sussex, England, almost one-fifth (18\%) of the participants stated that they were asked to prescribe anabolic steroids for non-medical reasons. In addition, $12 \%$ of general practitioners thought that physicians prescribed anabolic steroids with non-medical indications (21). In another study, it was found that $2 \%$ of athletes obtained anabolic steroids by means of general practitioners' prescriptions (22). Lack of knowledge on this subject is a problem that may lead to manipulation of physicians by athletes to benefit from medical indications.

In the study of Woods and Moynihan, most general practitioners (90\%) thought that both general practitioners and pharmacists played a role in preventing doping in sports; however, they found that only $9 \%$ felt that they were properly trained for this role (23). In another study, $89 \%$ of physicians thought that they played a role in preventing doping, a rate similar to that reported by Woods and Moynihan; however, more of these physicians stated that they received adequate training (27\%), (21). Woods and Moynihan reported that $24 \%$ of general practitioners in Ireland were assigned to a regular or special sporting event, but only half of that group received appropriate training about preventing doping (23). Considering that intern physicians may also have such duties in their professional lives, it is clear that the low knowledge levels that we found in our study should be increased.

In a study conducted with athletes in Japan, it was found that the correct response rates in the knowledge test were generally low, although participants thought that athletes should be familiar with the basic principles of WADA anti-doping rules during athletics competitions. In this study, results also showed that university athletes know that anti-doping applications are necessary to protect the spirit of sports and that cooperation is needed in doping control (24). Although the importance of the doping issue was found to be known in these studies, the low level of knowledge is an important point to consider.

Mazanov et al. concluded that physicians, assistant healthcare personnel, and coaches should be aware of and comply with the World Anti-Doping Code to avoid sanctions (25). Consistent with previous research, physicians and other support staff are at risk of sanctions due to lack of awareness of WADA obligations and lack of compliance (9).

The current data in the literature show that the educational and professional development of physicians related to sports and doping needs to be reviewed (9). When physicians are consulted about combating doping or drug use in sports, the lack of training and knowledge of the physicians makes it harder for them to provide accurate information and thus raises the risk of being misleading in terms of the athlete's health. This finding supports the view that unnecessary use of ergogenic supplements can be prevented when the attitudes and beliefs of people are in line with positive behaviors and increasing levels of consciousness (17). In this study, it has been observed that the presence of chronic diseases of the intern physicians, regular medication usage, and regular physical activity affected their attitudes towards nutritional ergogenic supplement use and doping. This is thought to be due to the fact that personal factors affect attitudes when the level of knowledge is low. Ercen, on the other hand, found in a study of male athletes that there was no statistically significant difference between chronic diseases diagnosed in athletes, regular drug use, and recent use of ergogenic supplements. The use of ergogenic support products among the athletes in that study was found to be related to the duration of sports and the frequency of participating in sports weekly. Similar to this study, attitudes towards the use of nutritional ergogenic supplements were associated with men's participation in physical activities (17).

One of our limitations is that the universe of our study consists of only senior students of a faculty of medicine. It is necessary to reach wider study populations in this regard and to determine the level of knowledge of intern physicians from different faculties as well as physicians working in the field and providing treatment to athletes. It will be useful to plan various educational activities for information by identifying the deficiencies and reviewing the subject in the medical education curriculum.

\section{CONCLUSION}

Knowledge levels of our intern physicians on nutritional ergogenic supplements and doping were found to be insufficient. The answers to the questions asked about the level of knowledge were not related to attitudes. It is thought that our participants' personal factors affected their attitudes due to their lack of knowledge. It is necessary to increase the knowledge of physicians in this field.

\section{Conflict of Interest / Çıkar Çatışması}

The authors declared no conflicts of interest with respect to authorship and/or publication of the article.

\section{Financial Disclosure / Finansal Destek}

The authors received no financial support for the research and/or publication of this article.

\section{REFERENCES}

1. Atasu T, Yücesir İ. Türkiye futbol federasyonunun dopingle mücadele tarihçesi. Editörler: Taşer ÖF, Bayraktar B, Futbol Hekimliği, 1. Baskı, Istanbul, Nobel Tıp Kitabevleri. 2019; 266-74.

2. olympic.org [Internet]. c2021 [cited 2021 Feb 03]. Available from:https://stillmed.olympic.org/media/Document\%20Library/OlympicOrg/IOC/Who-WeAre/Commissions/Disciplinary-Commission/2019/Antidoping-factsheet-retests-12062019.pdf.

3. Panagiotis G, Ourania D, Christos F, Jannis PS. Knowledge on and attitudes of doping in sport, of young trainees in internal and general-familial medicine. Pharmacologyonline. 2006; 2: 1-5.

4. Şensoy C. Türkiye voleybol 1. ve 2. liglerinde oynayan voleybolcuların doping bilgi seviye ve eğilimlerinin değerlendirilmesi. Master's thesis. Aksaray Üniversitesi Sosyal Bilimler Enstitüsü, 2018

5. World Anti-Doping Agency. The World anti-doping code. Montreal: WADA; 2003.

6. Yücesir İ. Futbolda doping ve dopingle mücadele. Editörler: Taşer ÖF, Bayraktar B, Futbol Hekimliği, 1. Baskı, Istanbul, Nobel Tıp Kitabevleri, 2019; 274-90.

7. Tipton CM. Sports medicine: a century of progress. J Nutr. 1997; 127(5): 878-85.

8. URL:http://www.guresdosyasi.com/makale1.html Access date: 15.11.2019 


\section{S. Ercan, A. Oğul, A. Canbulut, et. al.}

9. Backhouse SH, McKenna J. Doping in sport: A review of medical practitioners' knowledge, attitudes and beliefs. Int J Drug Policy. 2011; 22(3):198-202.

10. World anti-doping code. URL: http://www.wada-ama.org/en/World-Anti-DopingProgram/Sports-and-Anti-Doping-Organizations/The-Code. Access date: 13.11.2019.

11. Morente-Sánchez J, Zabala M. Doping in sport: a review of elite athletes' attitudes, beliefs, and knowledge. Sports Med. 2013; 43(6): 395-411.

12. Laure P, Kriebitzsch-Lejeune A. Retail pharmacists and doping in sports: Knowledge and attitudes. A national survey in France. Science \& Sports. 2000; 15(3):141-6

13. URL: http://www.tdmk.org.tr Access date: 06.10.2019

14. Alpar R. Spor Sağlık ve Eğitim Bilimlerinden Örneklerle Uygulamalı İstatistik ve Geçerlik Güvenirlik. Yenilenmiş 6. Baskı, Ankara: Detay Anatolia Akademik Yayıncılı;2020.

15. Argan M, Köse H. Sporcu besin desteklerine (sports supplements) yönelik tutum faktörleri: fitness merkezi katılımcıları üzerine bir araştırma. Spor Bilimleri Dergisi. 2009; 20(4): 152-64.

16. Şapçı HA. Üniversiteler arası spor müsabakalarına katılan öğrencilerin doping kullanımına yönelik tutumlarının incelenmesi. Yayınlanmamıs Yüksek Lisans Tezi, Sağı̌k Bilimleri Enstitüsü, Gazi Üniversitesi, Ankara, 2010.

17. Ercen Ş. KKTC'deki Fitnes ve Vücut Geliştirme Sporu ile Illgilenen 18-40 Yaş Grubu Sağı̆ıkı Erkek Sporcuların Beslenme Alışkanlıklarının Belirlenmesi, Besinsel Ergojenik Destek Ürünleri Hakkındaki Tutumlarının ve Kullanım Oranlarının Saptanması. Master's thesis. Eastern Mediterranean University, 2016.
18. Sinan MF, Koșar SN, Demirel AH. Vücut geliștirme sporcularının doping ve ergojenik madde kullanım eğilimleri. 9. Uluslararası Spor Bilimleri Kongresi Bildiri Kitabı, Nobel Yayın Dağı̆ım, Muğla, 2006; 9: 3-5.

19. Laure P, Binsinger $C$, Lecerf T. General practitioners and doping in sport: attitudes and experience. Br J Sports Med. 2003; 37(4): 335-8.

20. Greenway P, Greenway M. General practitioner knowledge of prohibited substances in sport. Br J Sports Med. 1997; 31(2): 129-31.

21. Perry HM, Wright D, Littlepage BN. Dying to be big: a review of anabolic steroid use. Br J Sports Med. 1992; 26(4): 259-61

22. Korkia P, Stimson GV. Anabolic Steroid Use in Great Britain: An Exploratory Investigation: Final Report to the Departments of Health for England, Scotland and Wales. Center for Research on Drugs and Health Behavior; 1993.

23. Woods CB, Moynihan A. General practitioners knowledge, practice and training requirements in relation to doping in sport. Ir Med J. 2009; 102(1): 8

24. Murofushi Y, Kawata Y, Kamimura A, Hirosawa M, Shibata N. Impact of anti-doping education and doping control experience on anti-doping knowledge in Japanese university athletes: a cross-sectional study. Subst Abuse Treat Prev Policy. 2018; 13(1): 44.

25. Mazanov J, Backhouse S, Connor J, Hemphill D, Quirk F. Athlete support personnel and antidoping: Knowledge, attitudes, and ethical stance. Scand I Med Sci Sports. 2014; 24(5): 846-56 